\title{
THE PRE-FRONT FIELD IN SPOKEN GERMAN AND ITS RELEVANCE AS A GRAMMATICALIZATION POSITION
}

\author{
Peter Auer
}

\section{The grammar of the pre-front field in German ${ }^{1}$}

In German and many other Germanic languages, there is no fixed order of $\mathrm{S}$ and $\mathrm{O}$ as in an SVO language such as English. Rather, the topology of the declarative non-dependent sentence is canonically defined by the position of the finite and (where relevant) the non-finite parts of the verb. Together, they build up the sentence 'brace', i.e., they define the front-field (before the finite verb), middle field (between finite and non-finite parts of the verb), and end-field (which often remains empty, but accommodates, for instance, post-positioned subordinate phrases). The front-field, also called topic position, may be filled by any constituent of the sentence, obligatory or non-obligatory. However, exactly one constituent (which, of course, may be of considerable complexity) can occupy this position. ${ }^{2}$ This restriction also applies to sentence adverbials and adverbial clauses, and to relative or complement clauses. Cf. the examples in Fig. 1.

English, of course, allows more than one constituent before the finite verb, for instance a subject preceded by a disjunct or conjunct (Quirk \& Greenbaum 1973: 242ff; also cf. Allerton \& Cruttenden 1974), or an adverbial clause. Cf. the translations of the German examples (a) and (c):

(a) Of course, one cannot make it on one's own.

(c) If I had had you here, I had gotten furious.

The only elements that may precede the front field according to the grammars of written standard German, however, are the true conjunctions und 'and', oder 'or', sondern 'but', denn 'for' and the (for other reasons) syntactically somewhat divergent conjunction aber 'but'.

\footnotetext{
${ }^{1}$ A more detailed syntactic account of the pre-front field spoken German - and many moe exemplary extracts taken from conversational materials - may be found in Auer (in press); also cf. Thim-Mabrey 1988.

${ }^{2}$ For a discussion of the front field and of some putative exceptions to the rule that $\mathrm{X}$ may only be one single constituent, cf. Faucher 1971; Schröder 1977/1984; van de Velde 1978. Clauses and phrases in the front field can be taken up by an anaphoric element, however; in this case of prolepsis, most grammarians of German argue that both the dependent clause and the anaphoric element are in the front field, possibly in a relationship of adjunction within the Comp-phrase. For details, cf. Selting 1993.
} 


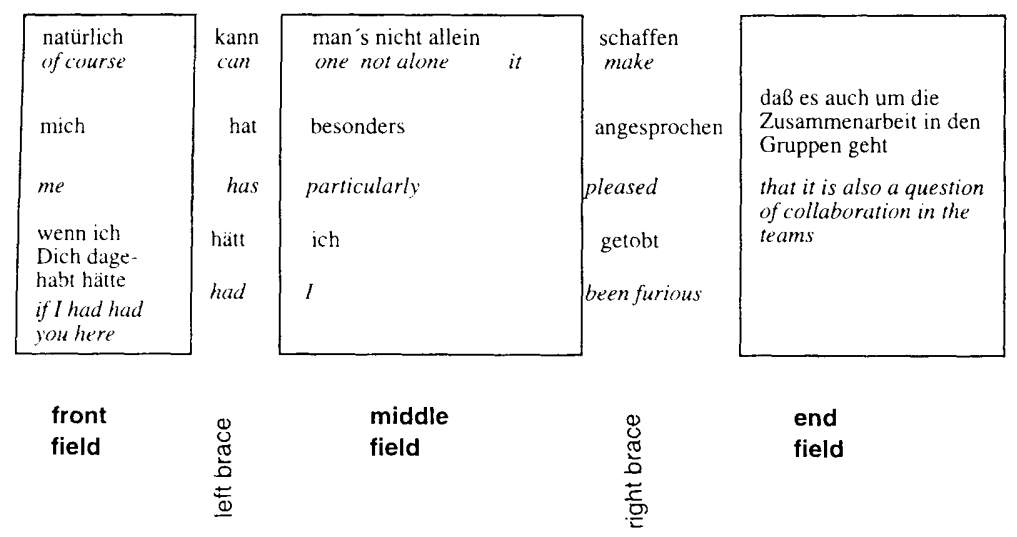

Fig. 1
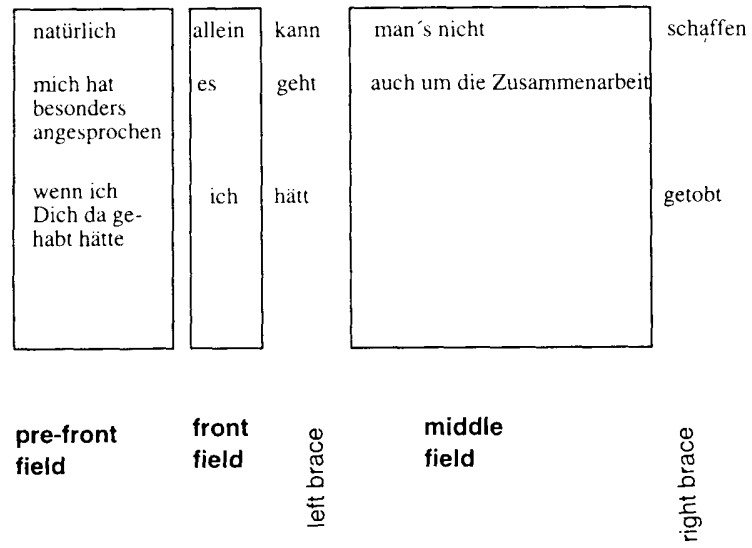

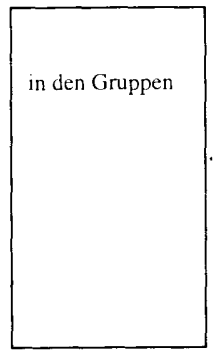

end

field

Fig. 2

While the above restrictions of German syntax hold for the standard, particularly in many of its written forms, spoken German (as well as some belletristic and journalistic written styles borrowing from it) are more liberal. Here, another constituent may precede the front field in certain well-defined cases. The topological position of these constituents I will call the pre-front field; see Fig.2.

The interest in the pre-front field position of German goes beyond the fact that it is little explored. It also central to an adequate understanding of the left margin (or beginning) of syntactic gestalts ${ }^{3}$ in German as a whole. As has been

3 I use the term "gestalt" instead of the more familiar "turn-constructional unit" or even "sentence" in order to refer to the following properties of spoken syntax: (a) that syntactic structures of spoken language are always emerging in real time; (b) that syntactically complete (i.e., potentially turn-constitutive) structures are not a property of the linguistic signal itself but the result of the hearer's understanding of this signal as it emerges; (c) that some complete utterances of this type are not syntactically unambiguous but can be assigned to different syntactic patterns, depending on their larger context, i.e. thhat syntactic well-formedness is an alltogether context-related issue, and 
repeatedly noticed by researchers of spoken syntax, the beginning and end of syntactic gestalts are often underdetermined in oral language. However, the right and left margin of a syntactic gestalt do not behave in a similar or even less in a mirror-image way. Termination (closure) of a syntactic gestalt is characteristically flexible and underdetermined because of its in-principle expandability (cf. Auer 1991, 1992, 1996; Schegloff 1996). The beginning (opening) of a syntactic gestalt is ambiguous or underdetermined if early constituents can be (re)defined as elements of various syntactic gestalts. Both expandability and syntactic ambiguity are technical solutions to interactional problems participants face in conversation: Expandability minimizes gaps and secures understanding, since it makes the termination of a syntactic gestalt-pattern negotiable between speaker and recipient, providing an important repair space. Early ambiguity minimizes gaps since it helps early starters to take over the turn without having to plan their subsequent utterance fully. In this sense, the German pre-front field position is, as I will argue here, a perfect opening device for a syntactic gestalt of spoken language, for its projecting force is weak and the gestalt opening therefore remains underdetermined.

Last, but not in the least, the pre-front field of German is of particular linguistic interest, because it is a preferred locus for processes of grammaticalization; by this I mean both processes by which interactionally grounded (sequential) patterns are routinized and sedimented into grammatical ones and processes by which adverbials turn into discourse markers. Note that (final) expandability and (initial) ambiguity are not syntactic issues per se; rather, they are primarily (and possibly universally) relevant in the domain of turn construction. If syntax, and in particular spoken syntax, displays construction types which mirror these turn-related construction principles, these construction types most likely are grammatical sedimentations of interactional structures.

This paper is structured as follows. I will give an overview of the ways in which the pre-front position is used in spoken German in section 2, and add some notes on its prosodic packaging and semanto-pragmatic interpretation in sections 3 and 4 . In section 5, I will point out how the various structures in the German pre-front field can undergo grammaticalization. Only a very limited number of examples will be discussed, due to limitations of space.

\section{Constituents in the pre-front field}

\subsection{Things that look like adverbials}

The list of German adverbials which can be placed in the pre-front field is similar, but in not identical with that of the "disjuncts" and "conjuncts" Quirk \& Greenbaum (1973) give for English. ${ }^{4}$ Here are some typical examples:

(d) that the syntactic whole is always more than its parts (constituents).

\footnotetext{
${ }^{4}$ For instance, Engl. personally, confidentially, fortunately, wrongly, surprisingly and others do not have German pre-front field equivalents. In general, the German adverb-forming derivative suffix -weise seems to be much less suited for producing pre-front field elements than the English $-l y$ adverbs: cf. fortunately vs. glücklicherweise.
} 
(1) ("Gleichgewicht 4" Fischer 1991 [radio phone-in/ advice-giving by therapist B])

B: $\quad=j a /$ jetzt kann ich schon verstéhn wie ihr problem ist - 'hh sie haben ganz früh gelérnt: 'h von sich e/ sélber: bissel ábzusehn, 'hh - u:nd eh vielléicht sich um:: die mútter oder:: leute in der umgebung - stark zu kulmmern:; hh und aus diesem múster:: beziehn sie jetzt auch - ehm - ihren wert $=$ namlich des $/$ mú $\beta$ unbedingt so sein=man muß sich überwiegend um die anderen $k$ ümmern, dánn: muß es gútgehn; =

A: $\quad=h$ néin das möcht ich nich unbedingt sagen

B: $\quad$ yes/ now I can understand what your problem is - 'hh you learned at a very young age: ' $h$ to disregard eh/ yourself a little bit, ' $h \mathrm{~h}$ - a:nd eh maybe to care for: your mother or:: people in your surroundings - very strongly:; 'hh and out of this pattern:: you still take your own - ehm - self-esteem = namely it/ has got to be like that at all costs=one has to care for others above all, then: things are o.k.; =

A: $\quad=h$ no I wouldn't in fact say that

(2) ("Bulimie 9231: 31" [group therapy session]) $)^{5}$

U: $\quad$ ja; =aber dann immer die ' $h$ die wăhl auch; zwischn jémandem und zwischn essn.

TW: ja?

$\mathrm{U}$ : also 'h [aber naturlich ganz allein denk=ich sch]afft

TW: $\quad$ [jedenfalls der griff wa:r ]

$\mathrm{U}: \quad$ mers nich, $\quad$ [as ]o ingnd =ne hilfe bràcht mer. =nur halt

TW: $\quad$ [ja:]

$\mathrm{U}: \quad$ andre vleicht, $=$ wie $s$ essn; ne

$\mathrm{U}$ : $\quad$ yeah; = but then always the ' $h$ choice too; between somebody and between eating.

TW: yeah?

$\mathrm{U}$ : you know 'h [but obviously just on your own I think you can't make it

TW: [at any rate you grasped

U: $\quad$ [I mean some kind of help you need.=

TW: [ye:s

$\mathrm{U}: \quad=$ only different maybe from eating; you know

(3) ("Hausrat 4, 4" Stern [telephone conversation with the sales representative of an insurance company])

$\mathrm{Kd}: \quad$ da muß man jetzt natürlich professionéll rangehen; ich als privatmann habe keine chance mehr;

$\mathrm{V}: \quad$ ja=ja; nee=nee; professionéll können wir da rangehen, dázu sind wir lange genug am márkt; das ist also eigentlich kéin - kéin problem was man nicht lösen könnte;

Kd: $\quad m h m$,

$\mathrm{V}: \quad$ núr; das ist mit nem finanziellen aufwand verbunden; [und ich

Kd: $\quad[m h m$.

V: $\quad$ mein; Sie haben natürlich irgendwo récht ((...))

$\mathrm{Cl}$ of course now one has to approach this in a professional way; I myself as a private person don't have another chance;

R: $\quad$ sure $=$ sure; no=no; professionally we can approach it, we are long enough on the market

5 "Bulimie" -data reproduced by kind permission of the "Ulmer Textbank" (Sektion Informatik in der Psychotherapie am Klinikum Ulm). 
for that; this is not really a - a problem that could not be resolved;

Cl: mhm,

R: only; this implies a financial effort;

R: [and I mean; of course you are right ...

Cl: [mhm.

That the topological position before the front field is involved in these examples can be seen from the following schematic representation (the English version is a quasi-linear translation):

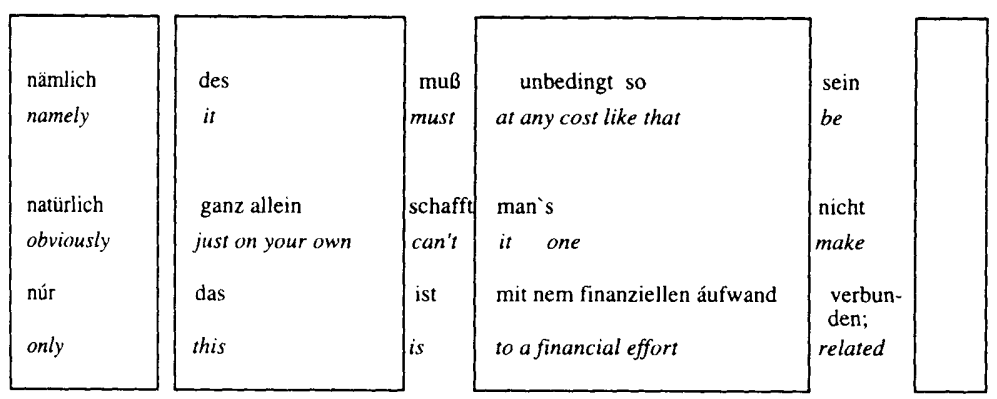

\begin{tabular}{|c|c|c|c|c|}
\hline $\begin{array}{l}\text { pre- } \\
\text { front } \\
\text { field }\end{array}$ & $\begin{array}{l}\text { front } \\
\text { field }\end{array}$ & 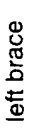 & $\begin{array}{l}\text { middle } \\
\text { field }\end{array}$ & 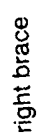 \\
\hline
\end{tabular}

Fig. 3

Apart from simple lexical items such as nämlich, natürlich or nur, more complex constituents may be used (including participle constructions such as genau gesagt 'strictly speaking', noch einmal 'once more', the topicalizer/cleft construction was $X$ betrifft 'regarding X', or infinitival constructions such as um gleich mal auf Fakten zu kommen 'to come to the facts right away' or um es mal ganz klar zu sagen 'to put it plainly'.

\subsection{Things that look like 'dependent clauses'}

Pre-front field constituents may also contain a finite verb, such as in the following cases of conditional and temporal wenn-clauses:

(4) ("Dreieck" Fischer [radio phone-in show; advice-giving]) 
B: $\quad=$ 'hhh $=$ ganz $=$ ganz wichtig ist $?$ 'hh daß sie miteinander ins gespräch kómmen?=oder im gespräch bléiben, 'h und dabei jéder seine gefühle - äußern darf ['hh]

A:

B: $\quad a h:: m$ daß ihr: pártner von seiner eifersucht erzählen darf $=$ [und]

A: $\quad$ [a::]

[mhm]

B: $\quad=d a \beta=s i e:$ ' $h$ ah/ son bißchen sich weiter

A: $\quad[\mathrm{ah:}] \quad[\mathrm{ja}]$

kenn [lern]en in [ihr]en motiven, =

$=$ wenn ich da mal kurz réingehn darf;

B: $\quad[\mathrm{hm}]$

A: $\quad h$ also äh jeder mensch hat léider nicht die möglichkeit sich so gut äh zu artikulieren äh $=w /$ wie ich's vielleicht zum teil kann

B: $\quad=$ 'hhh =very=very important is? 'hh that you come to talk to each other?=or keep talking,

' $\mathrm{h}$ and that each of you is allowed to - talk about his feelings [' $\mathrm{hh}$

A: $\quad$ [mhm

B: ehm that you:r partner is allowed to talk about his jealousy $=$ [and

A: $\quad$ [a::

B: =that you ' $h$ eh/get to know each other a [little bit in [your motivations,=

A: [eh: [yes

$=$ if I may come in at this point briefly; that is=

$=$ [that is part of the problem;

B: $\quad[\mathrm{hm}$

A: ' $h$ you know eh not everybody unfortonately has the possibility to make himself eh understood as well $\mathrm{eh}=\mathrm{a} /$ as I possibly partly can

(5) ("Bulimie 9231:50" [group therapy session; Alemannic dialectal variety])

A: ds hat schó so phase gee wo i so wahnsinnig (0.5) depréssiv war weil i mir mei zukunft - it vórstelle- konnt; (2.0) und - wenn $\underline{i}$ jetzt ehrlich $\underline{\text { bi }}$ - $h$ (1.5) $\underline{i}$ ká: se mir jetzt zwar bissle vorstelle, aber $i$ ha trotzdem no angscht -

A: there were times when I was so madly (0.5) depressive because - I couldn't imagine a future - for myself; (2.0) and/ - if I am honest - $h$ (1.5) I can imagine one a little bit now, but still I have fear

(6) ("Schiedsrichter" [telephone conversation between mother and son])

A: ja Karsten, is der pappa schon dá gewesen?

$\mathrm{K}: \quad n e$,

A: jetzt bleibst du ma auf jéden fáll zu háus und wenn der kómmt; in Bíberach is heut kéin spièl, =

$\mathrm{K}: \quad=j a-$ moment ich schreibs mir auf.

A: yes Karsten, has dad been in?

K: no,

A: now you stay at home at all events and if he comes; there is no match in Biberach today, $=$ $\mathrm{K}: \quad=$ yes - just a minute $\mathrm{I}$ take it down.

Once more, a clear deviation from the usual XV...-pattern is involved; see Fig. 4. With the 'adverbs' of the preceding section, these clauses share the characteristic feature of all pre-front field structures, i.e. to project syntactically into the following space without defining one particular syntactic gestalt. On its own, the adverbial clause would not, in its particular context, form a full syntactic gestalt. However, 
since the following clause starts with the usual front field, it shows no orientation whatsoever to syntactic embedding. ${ }^{6}$ Pre-front field clauses such as in (4) - (6) therefore are not integrated hypotactically into a complex sentence, or at least not in they way hypotaxis is construed in written German, although they project for something more to come. As a consequence, it is difficult to classify the preceding clause as dependent or subordinated as well: Although clause-type pre-front field constituents are introduced by a subjunction (such as, in this case, wenn), indicating subordination, they are not integrated into some complex sentence by word order and are therefore topologically non-subordinated. ${ }^{7}$

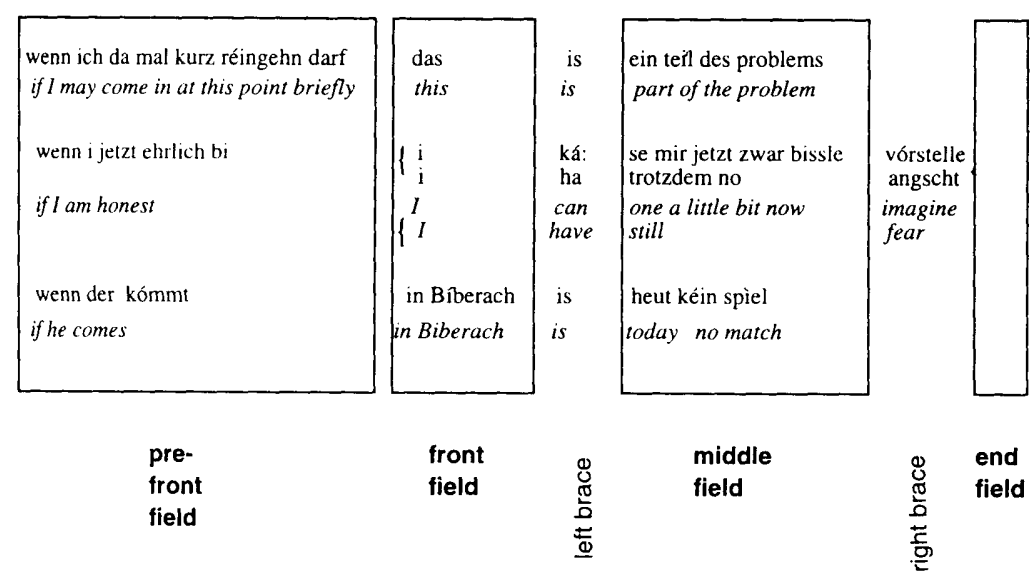

Fig. 4

\subsection{Things that look like 'noun phrases'}

The following examples represent what some linguists would call 'hanging topics': ${ }^{8}$

(7) ("Allein 2" Fischer 1991 [radio phone-in show])

A: $\quad$ 'hh und dann háb ich an bekánnten angrufen? daß er mich hólen soll - und mei sachen auch runterdu soll;

${ }^{6}$ In written standard German, "main clauses" - i.e. matrix clauses in a complex construction -

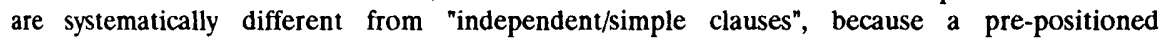
subordinated clause has to be produced in the prefield and thereby bans other constituents from this position.

${ }^{7}$ Cf. Matthiessen \& Thompson 1988 for a discussion of the squishiness of "subordination".

${ }^{8}$ For left-dislocations, cf. note 1. 
$(0.8)$

u[::nd ] dann war's só un mei múdda?

B: $\quad\left[{ }^{\circ} j a,{ }^{\circ}\right]$

A: - síe will ez am gerícht gegen mich ausságen? 'h daß ich angeblich ein liébhaber hab;

A: 'hh and then I called a friend? he should pick me up - and also bring down my things; $(0.8)$

a[::nd then it was like this my mother?

B: [yes,

A: - she now wants to testify against me in court? 'h that I allegedly have a lover;

(8) ("Bewerbung II 2:25" [role-played job interview])

IM: (...) wollen wir betreffende per'son ah - informieren = beziehungsweise auch die andern natürlich $(0.5)\{>\}$ die denn: ah aus dem rennen rausgefallen sind;

B: $\quad m h m$,

IM: $\quad\{<\} a ̈ h-z e ́ i t r a u m:,=$ wir $\{>\}$ sch'atzen daß des ah (0.5) sicherlich zwéi wòchen dáuern wird, ah Sie mulssen sich also - mit der ántwort ah: ((schluckt)) zwei wochen gedúlden? (0.5)

IM: (....) we will inform the person eh - concerned $=$ or rather the others as well of course $(0.5)$ who then drop out

B: $\quad \mathrm{mhm}$,

IM: eh - time:, =we assume that this eh $(0.5)$ will surely take two weeks, eh so you have to be - patient waiting for an answer ((swallows)) for two weeks

(9) ("Bulimie 9226:2" [group therapy, Alemannic dialect])

C: do war im gschäft it viel; ' $h$ des $=h a b=i=d e n n=s c h o$ as en grúnd gnumme zum ésse; - oder dehoim, die hend vielleicht $-\ddot{o} /$ bloss e kléinigkeit gsait, $=i t$ temol oder =oder nix gsait do war eigentlich gar it viel do; ha i des áu gnumme zum esse;

C: there wasn't much to be done in the office; ' $h$ this I took as a reason for eating already; or at home, they maybe just - e/ said a tiny thing, =not even or $=$ or said nothing it really wasn't much after all; I also took it as a reason for eating;

Again, a look at the topological structure shows the position of these phrases in front of the front field:

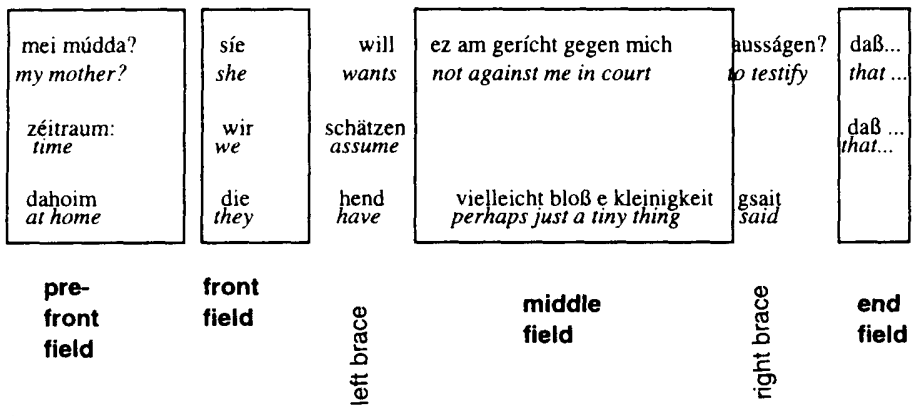

Fig. 5 
Extract (9) also makes it clear that the classification of the examples of 2.1. as adverbial-like and those under the present heading as phrase-like is not unproblematic: Functionally, the phrase 'at home' belongs to the group of hanging topics - vaguely speaking, it introduces a new subtopic or example to support the argument; yet, its morpho-syntactic classification is fully compatible with that of an adverbial.

\subsection{Things that look like 'conjunctions'}

Since true conjunctions precede the topic position in spoken and written, we are here interested in the typically oral use of certain subjunctions of written German such as weil 'because', obwohl 'although' and wobei 'although, however' only. ${ }^{9}$ In spoken, but not written standard German, they may also introduce clauses which show all the characteristics of independent sentences:

(10) ("Pollen" [telephone conversation, two students])

B: $\quad$ du hattest son bréitbandschnupfen;

A: ja ja (.) so lab ende april

B: $\quad$ [hm klasse;

A: $\quad$ wobei (.) ich hab féstgestellt daß es nicht zwíngend die pollen sind=die mich dahinraffen $~$ sondern eher $s=o z b n$;

B: $\quad s=o z o ́ n ?$

A: $\quad$ jo - weil pollenflug is bei diesem wetter auch; ((etc.))

B: $\quad$ you had kind of a wide spectrum cold;

A: yes yes (.) like [from the end of April onwards

B: $\quad$ [oh great;

A: however (.) I noticed that it need not be the pollen which carry me off but rather the ozone;

B: the ozone?

A: yes - because pollen we have as well in this weather

If used in this way, these words assume an ambiguous syntactic status, sometimes switching category from subjunction to conjunction; see Fig. 6.

\subsection{Things that look like sentences without obligatory objects}

This group of examples exemplifies a pre-front field phenomenon which is not regularly seen as being related to the others. Yet, syntactic - and, as we shall later see, functional - reasons strongly suggest grouping it with them.

${ }^{9}$ For a fuller discussion, cf. Günthner, in this issue. Wobei has no straightforward English translation; it is a compound of a relative pronoun wo and a preposition bei. 


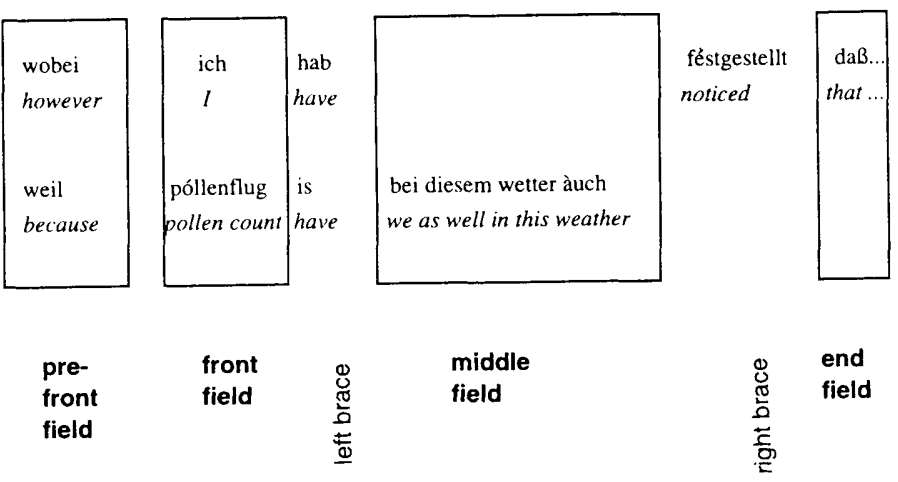

Fig. 6

(11) ("Bewerbungsgespräch KN 2:7" [role played job interview])

B: das is ja grade das réizvolle an der aufgabe. - [also:

IF: $\quad[\{p p\} m m$

B: $\quad$ - mích: hat besónders angesprochen - ah Sie: - Sie légen wert auf $-f^{\prime}$ ührungsqualitäten, $=a b e r$ 'hh ich hatte den éindruck daß es eben im wésentlichen auch (.) um die zusámmenarbeit mit anderen gruppen geht, 'hh ((etc.))

B: this is so exciting about the job. - [you see:

IF: $\quad$ [mm

B: $\quad$ I was particularly taken with eh - you: - you insist on - management qualifications,=but ' $\mathrm{h} h \mathrm{I}$ had the impression that basically what is involved is also (.) the cooperation with other teams, "hh ((etc.))

(12) ("Wahrsagerin 4" [radio phone-in show with a fortune-teller]) ((caller S. wants to know if she should venture into a new business; $\mathrm{W}=$ fortune teller, $\mathrm{M}=$ moderator $))$

W: $\quad$ st'ürzen Sie sich voll drauf;

S: $\quad j a \sim$

M: Sigi, (.) - jetzt muß ich Ihnen natülich tròtzdem sagen, Sie wissen, Sie haben béide möglichkeiten, Sie m'üssen es nicht machen?

W: throw yourself right into it;

S: $\quad$ yeah

M: Sigi, (.) now of course I have to tell you nonetheless, you know, you have both possibilities, you do not have to do it.

(13) ("Dianachmittag" Bergmann 1994) [familiy looking at holiday slides;Swabian dialect $\left.{ }^{10}\right]$ )

${ }^{10}$ Transcription of Swabian dialect features follows the representation given by the author. 
M: $\quad$ jö̈ $=$ joä, (ihr sind) írgend wo uff em gípfl im schnée rumgrochä und nemme wiederkommä.

((Diawechsel; jemand zieht die Nase hoch, jemand hustet))

E: (dä balko: $n$ runder.)

$\mathrm{U}: \quad$ doä bin ich scho

\section{[nimme mid in Lúrlaub; $\Gamma^{\circ}(d=\text { mudder })^{\circ}$}

C:

$\mathrm{L}$

U: doa [war $i$ : schon gróß, ehh

\section{$I^{\circ} \mathrm{mhm}{ }^{o}$}

D: [felld $\underline{\text { mer }}$ grad $\underline{a i}=s c h o ̈ n e n ~ g r u: \beta$ von Br'üschdles? und die=hend=scho $=$ wieder $=$ da $=$ nägschde nóachwuchs. -

M: wer?

M: yeah yeah (you were) crawling about somewhere on a mountain peak in the snow and you didn't come back

((change of slides, somebody sniffs, somebody coughs))

$\mathrm{E}$ (down the balcony)

$\mathrm{U}$ : there I am not [any longer with you on [holiday

C: $\quad[$ (mother)

L: $\quad[\mathrm{mhm}$,

$\mathrm{U}$ : there [I was grown up already, ehh

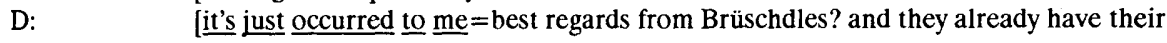
next offspring [[child]]

After verbs such as jemanden ansprechen (to be taken with), sagen (to say), wissen (to know), jemandem einfallen (to occur to somebody), German requires an object which, if it is not a phrase but a clause, needs to be introduced by subjunctions such as $d a \beta$ ('that') or $o b$ ('whether') in the written standard language. On its own, the pre-front field 'matrix sentence' is not a full syntactic gestalt and therefore no turn-constructional unit. In the above examples of conversational language, however, the subjunction is lacking and the clausal 'complement' necessary to close the gestalt has the word order of independent sentences instead of the verb-final constituent order to be expected in a subordinated clause; see Fig. 7. The analysis proposed here differs from the more traditional one according to which the subjunction $d a \beta / o b$ would be said to be elided by some kind of ellipsis; see Fig. $8 .^{11}$ It reverses the hierarchical relationship between the clause containing the verbum sentiendi, dicendi, etc., and the clause which semantically represents the object of saying or meaning (for which the German term Inhaltssatz - lit. 'content clause' - is not unfelicitous), and in doing so, it is in line with the functional-pragmatic analysis of subordination as a backgrounding strategy. (The more important information is of course contained in the 'content sentence', not in the preceding clause with a verbum dicendi, sentiendi, etc.)

The enormous popularity of this structure is probably due in part to the fact that it is also used in written standard German in a restricted environment, i.e., for direct speech (type: Xaver said: This is true.). In spoken German, the pattern extends far beyond verba dicendi (and even sentiendi). The exact syntactic and lexical conditions for this oral usage of the pre-front field still need to be explored.

\footnotetext{
${ }^{11}$ The ellipsis-interpretation is also found for English in Quirk/Greenbaum 1973: 317.
} 


\begin{tabular}{|c|c|c|c|c|c|}
\hline $\begin{array}{l}\text { mích: hat besónders angesprochen } \\
\text { I was particularly taken with } \\
\text { jetzt muB ích Ihnen natürlich tròtzdem } \\
\text { sagen } \\
\text { Sie wíssen } \\
\text { now of course I have to tell you } \\
\text { nonetheless } \\
\text { you know } \\
\text { felld mer grad ai } \\
\text { it's just occurred to me }\end{array}$ & $\begin{array}{l}\text { Sie: } \\
\text { you: }\end{array}$ & $\begin{array}{l}\text { haben } \\
\text { have }\end{array}$ & $\begin{array}{l}\text { béide möglichkeiten } \\
\text { both possibilities } \\
\text { schönen gru:B von Br üschdles } \\
\text { best regards from Brüschdles }\end{array}$ & $\begin{array}{r}\text { wert } \\
\text { auf }\end{array}$ & $\begin{array}{c}\mathrm{f} \text { ührungs- } \\
\text { qualitäten } \\
\text { management } \\
\text { qualifications }\end{array}$ \\
\hline $\begin{array}{l}\text { pre- } \\
\text { front } \\
\text { field }\end{array}$ & $\begin{array}{l}\text { front } \\
\text { field }\end{array}$ & 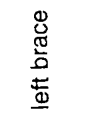 & $\begin{array}{l}\text { middle } \\
\text { field }\end{array}$ & 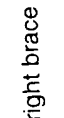 & $\begin{array}{l}\text { end } \\
\text { field }\end{array}$ \\
\hline
\end{tabular}

Fig. 7

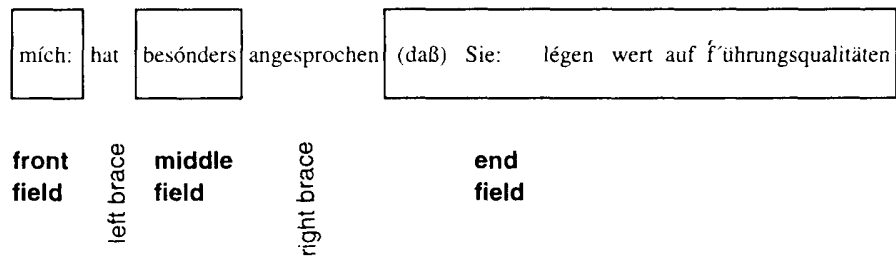

Fig. 8

\subsection{Address terms and other attention-getters}

The final group of pre-front field constituents consists of 'vocatives' in the form of address terms (names, titles, second person pronouns, or combinations thereof), of expletives (equivalents of gosh, shit, etc.) of particles used as attention getters (such as hey!, na!,) and of imperatives used in the same function (komm! 'come', hörmal! 'listen'). This is not a non-standard, but rather standard usage of the pre-front field, but as vocatives and other attention-getters typically occur in oral language, they are included in this discussion:

(14) ("Horch" [telephone conversation; Bavarian/East Franconian dialect])

B: $\quad$ ich würde =mal auf jeden fall ságen,

$\mathrm{F}: \quad j a$,

B: daß du den ganz schnell anrufst $[. .$.$] du möchtest die maschíne gerne$ haben $=$ únd $=$ so $=$ weiter; $=$ des brauch $=i$ dir net erzäjn; ' $h$ rúf mal an, $i=b i n=g s c h p a n n t$ was er dír erz'ählt dann; = 
$\mathrm{F}: \quad=\underline{h o r c h=e=m a l}$ d/ de hád=doch der uns o:ngebo:dn um weviél?

B: $\quad$ in any case I should say

F: yes,

B: that you phone him right now [omission ] you want to have the machine etc etc; =I don't need to tell you; ' $h$ phone him, I am curious to hear what he will tell you; =

$\mathrm{F}: \quad=$ listen $\mathrm{h} / \mathrm{he}$ made an offer for us didn't he

(15) ("Ro I,1" [role played job-interview])

I1 >12: ich würd Sie (ganz/dann) vielleicht mal bitten, - bitten die ( $>$ ) erste fráge zu stellen.\#

I2: (2.0) herr lohmann eh - ich hab mich natürlich mit ihren unterlagen besch'äftigt? vielleicht könnten=se gánz kurz noch mal zusámmenfassend; eh - dárlegen; - eh ihre (.) berufliche entwicklung?

I1 $>$ I2: I would like to ask you perhaps, - ask you to ask the first question.

I2: (2.0) Mr Lohmann eh - of course I have read your application? maybe you could summarized in a few words eh - eh your (.) career development?

As the other pre-front field constituents, vocatives of this type project some following syntactic structure without obliging the speaker to chose a particular pattern. Schematically, they may be represented as follows (in (14), the pre-front field is additionally occupied by a hanging topic):

\begin{tabular}{|c|c|c|c|c|c|}
\hline $\begin{array}{l}\text { horch emal } \\
\text { listen } \\
\text { Hert Lóhmann } \\
\text { Mr Lohmann }\end{array}$ & de & $\begin{array}{l}\text { hat } \\
\text { has } \\
\text { hab } \\
\text { have }\end{array}$ & $\begin{array}{l}\text { doch der uns } \\
\text { he to-us } \\
\text { mich natürlich mit ihren Unterlagen } \\
\text { me of course with your application }\end{array}$ & $\begin{array}{l}\text { o:ngebo:dn } \\
\text { offered } \\
\text { besch'äftigt } \\
\text { occupied }\end{array}$ & \\
\hline $\begin{array}{l}\text { pre-front } \\
\text { field }\end{array}$ & $\begin{array}{l}\text { front } \\
\text { field }\end{array}$ & 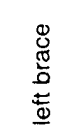 & $\begin{array}{l}\text { middle } \\
\text { field }\end{array}$ & 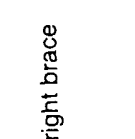 & $\begin{array}{l}\text { end } \\
\text { field }\end{array}$ \\
\hline
\end{tabular}

Fig. 9

\section{The prosody of the pre-front field}

In the preceding section, I have presented six types of pre-front field constituents in spoken German. They may be ordered on a continuum of syntactic complexity, from simply words to clause-like constructions. As some examples show, more than one constituent may be positioned in the pre-front field.

I have suggested that the pre-front field should be treated as the very beginning of a syntactic gestalt, emerging in-time as the speaker begins to construe his or her turn or turn-component. Note that during the production of the constituent in question, its syntactic status is completely open; it may turn out to occupy the front field, or rather the pre-front field, for instance. Only after the left sentence brace has been produced do recipients know what the constituent's 
syntactic status is. So the emergent gestalt is underdetermined during its production. Nevertheless, a syntactic gestalt is emerging; no turn constructional unit could possibly be said to have been completed after their production, in the given context.

In this section, the following two questions will be asked:

a) Is the pre-front field realized as an intonational phrase (contour) of its own or is it integrated into the following contour? In the first case, prosody exposes the pre-front field, giving it pragmatic weight and relevance; its syntactic status is highlighted, and the pre-front field and the following structure may be said to represent an "idea unit" each (Chafe, e.g. 1985). In the second case, the syntactic position of the pre-front field is treated just as any other syntactic position within the emergent syntactic gestalt; its special syntactic status is not underlined by prosody. Rather, intonation camouflages syntax.

b) In the case of a prosodically exposed pre-front field, is the pre-front field contour terminated by an upward or downward pitch movement, or rather by level intonation?

A look at the data shows that both prosodically exposed and prosodically integrated pre-front fields occur; choosing one or the other seems to be in part a function of the length and syntactic complexity of the pre-front field constituent. The shortest of these constituents are conjunctions, and they are rarely produced as an intonational phrase of their own; the longest constituents are quasi-dependent clauses (type 2.2.) and clauses with verba sentiendi and dicendi (etc.) (type 2.5.). They usually constitute independent contours. But length and complexity surely do not determine the prosodic packaging of a pre-front field constituent. For instance, hanging topics (2.3.) and vocatives (2.6) are very often realized as contours of their own, while adverbials (2.1.) appear in either prosodic packaging. Yet, they are of similar size.

As an example, consider the stylized fundamental frequency $\left(f_{o}\right)$ extractions (roughly corresponding to perceived pitch movements) for examples (2), (3) and (1). (2) and (3) show exposed pre-front fields with a nuclear pitch movement and final boundary movement. (Pauses delimiting the pre-front field occur, but are rather rare.) In (2), both phrases have a nuclear pitch movement (on the syllables natürlich and $g a n z$ ), the beginning of the second phrase is additionally marked by a downstep of pitch register. In (3), nuclear pitch movements may be found on nur and Aufwand, and the second phrase is additionally marked by an upstep on das...; see Fig. 10 and Fig. 11. On the other hand, ex. (1) shows prosodic integration; see Fig. 12. In this case, a phrase boundary occurs before the adverbial in question (nämlich) which is integrated smoothly into the series of anacrustic syllables leading up to the accent on $m u \beta$.

How the pre-front field is handled therefore cannot be deduced from the type of pre-front field constituent we are dealing with. Rather, prosodic integration or exposure are contextualization cues upgrading or downgrading the pragmatic relevance of the pre-posed elements in specific ways that need to be analyzed in context. 


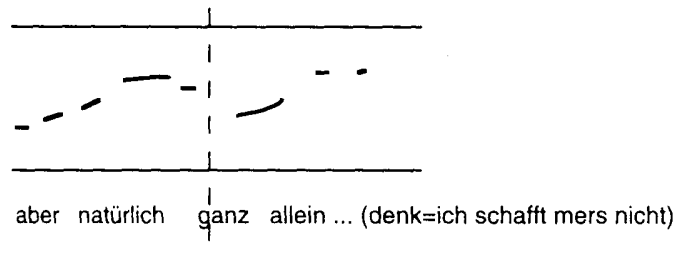

Fig. 10

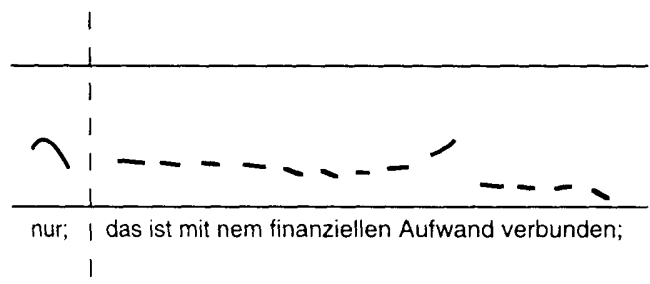

Fig. 11

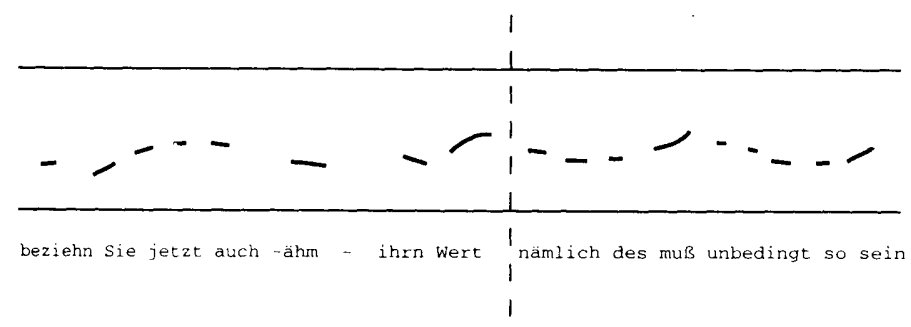

Fig. 12

If the pre-front field is exposed prosodically, the final pitch movement characteristically is not a that of a 'continuing' intonation (i.e., a moderately rising post-nuclear contour), but rather level or even falling (as in (2), (3) or (6), repeated here in prosodic transcription).

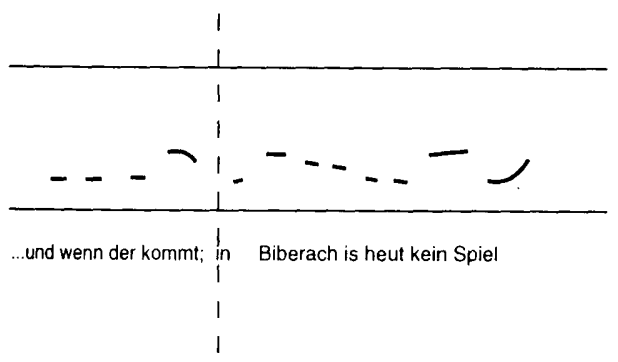

Fig. 13

This prosodic marking for a prosodic junctures within a complex syntactic construction is clearly exceptional in German. Some researchers have interpreted the absence of the more usual 'continuing' intonation as a prosodic indicator of 
syntactic ellipsis, at least in a non-integrated conditional/temporal clause such as (6).$^{12} \mathrm{~A}$ simpler and more general explanation might be the following: The marked prosodic pattern is a cue for the recipient that the constituent just about to be completed is not the front field constituent (which it could be in morphosyntactic terms), but rather a pre-front field constituent.

\section{Discourse functions of the pre-front field}

The general function of the pre-front field is to frame the subsequent utterance, i.e. to provide some information which is important for its understanding. This framing function includes metalinguistic comments, but also many other functions.

Metalinguistic (and indeed, metapragmatic) framing in the strict sense occurs when an aspect of the activity that is going to follow is formulated, e.g.,

- its position or function in a text (as in (1), where the pre-front field announces an explanation)

- its turn-taking status (as in (4), where the pre-front field announces an interruption, or (13), where it accounts for the out-of-the-blue production of this utterance)

- its addressee (as in the vocative of (15)).

Metapragmatic framing in the pre-front field is also involved in the so-called epistemic use of weil 'because', as in

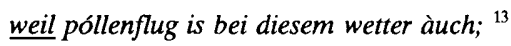

because pollen we have as well in this weather

Clearly, in this case, it is not the fact of pollen in the air which causes the speaker to react to ozone, but rather, the fact that ozone and pollen concentration is high during the same periods is the reason for her to believe that she reacts to ozone rather than pollen.

Sometimes, the metapragmatic information conveyed by the pre-front field constituent is quite complex, such as in

und wenn der kommt; in Biberach is heut kéin spiel,

and if he comes; there is no match in Biberach today,

where the conditional/temporal clause specifies the conditions under which the following utterance becomes pragmatically important.

Framing functions of the pre-front field also include modalization when the

12 The elliptical constituent, according to this view, is a verbum dicendi such as dann sag ihm 'then tell him'.

${ }^{13} \mathrm{Cf}$. Günthner, in this volume; Couper-Kuhlen, in this volume for a prosodic treatment; Sweetser 1990 for the terms "speech act related" and "epistemic". The same meta-pragmatic status could be conceded to speech-act related used of causal clauses discussed by the same authors. 
speaker's or some other person's or group of persons' perspective on the following statement is expressed. In the data presented here, this applies, for instance, to ex.

$\underline{\text { wenn }} \underline{\underline{i} \text { jetzt }} \underline{\text { ehrlich }} \underline{\text { bi }}-h$ (1.5) $\underline{i}$ ká: se mir jetzt zwar bissle vórstelle, aber $i$ ha trotzdem no angscht -

if $\underline{I}$ am honest - $\mathrm{h}(1.5)$ I can imagine one a little bit now, but still I have fear

Another frequent function of the pre-front field is connective framing. In this case, the pre-front field constituents establish a semantic relationship between the preceding and the subsequent utterance, or rather, their respective propositional contents. Their semantics is similar to that of the traditional conjunctions and subjunctions. For instance, in extract

(3) núr; das ist mit nem finanziellen áufwand verbunden;

only; this implies a financial effort;

and

(10) wobei (.) ich hab féstgestellt daß es nicht zwingend die pollen sind=die mich dahinraffen sondern eher s=ozón;

however (.) I noticed that it need not be the pollen which carry me off but rather the ozone;

nur and wobe $i$ express a relationship of qualification or restriction very similar to the conjunction aber 'but' or the subjunction obwohl 'although. Pre-front field constituents of this kind therefore enrich the repertoire of verbal means to express fine-grained semantic relations between propositions. ${ }^{14}$

Finally, topical framings (re-)introduce new topics, sub-topics or referents, cf., for instance, ex.

oder dehóim, die hend vielleicht - 0 / bloss e kléinigkeit gsait

or at home, they maybe just - e/ said a tiny thing,

Even from the very few examples discussed here it is obvious that there is no strict correlation between the form of the pre-front field constituent and its framing function; functions may typically be expressed by structures from more than one group.

To state positively what kind of pragmatic framing is served by the pre-front field position does not yet answer the negative question why the same pragmatic ends could not just as well be reached by using the same constituents in their canonical position, i.e. in the front, middle or (in the case of clauses) end field. Apart from turn-taking considerations (pre-front field supports early starters), the following points need to be taken into account for answering this question:

First of all, many pre-front field constituents cannot be moved into one of the other positions under denotational equivalence, some not at all. For instance, if the

14 It will be noted that this finding contradicts the stereotype that oral language typicallyy lacks the verbal means to express relations between propositions in a sophisticated way, an assumption that played an important role in Bernstein-type sociolinguistics. 
adverbial nur of ex. (3) (núr; ist das mit nem finanziellen aufwand verbunden) is moved into the middle field, an alternative if not dominant semantic interpretation comes into play: The scope of the adverbial is narrowed down to the subsequent NP (das ist nur mit nem finanziellen Aufwand verbunden). Similar ambiguities or semantic shifts occur with the pre-front field constituents of (1), (4), (5), (6) ${ }^{15},(10)$ (weil). Some pre-front field constituents cannot be moved into another topological position at all (cf. hanging topics such as in (8), or address terms); sentences without obligatory objects (cf. section 2.5.) also require different transformations, if the pre-front field is to be avoided.

But even where the pre-front field constituent could be moved into another position under semantic equivalence, the pre-front field has a number of interactional and cognitive advantages. Above all, it is iconic: the frame is clearly separated from the framed structure, and it precedes it. Cognitively, this ensures that the context in which the following utterance is to be processed is available from the very start of the interpretation process, thus avoiding cognitively and/or interactionally demanding repair work. The canonical structure of (written) standard German is not well suited for this kind of iconic framing. Although the front field could be used for it, there are other things that need to be taken care of in this position. In particular, referential continuity is at stake, and topical material needs to be introduced here ('topic position'). There is, then, only one topological position available for a multitude of things that need to be done in the beginning of an emerging syntactic structure in standard (written) German. The pre-front field of spoken German is a nice solution to this problem; it allows dealing with framing matters and reserves the front field for referential continuity.

\section{Grammaticalization in and through the pre-front field}

I have been cautious to use terms like 'adverbial' or 'conjunction' in an unhedged way in section 2 . The reason is that these categories are usually defined in syntactic terms; yet, these syntactic definitions never take into account spoken syntax. If the same terms are used for the constituents in a syntactic position which is typical for spoken German but of restricted relevance for canonical written language, their meaning becomes metaphorical at best: In these positions, 'decategorialization' takes place. The syntactic problems are obvious. What we have called 'adverbials' are structures that can hardly be dealt with on a par with 'sentential adverbs' in written German syntax, for the first lack the freedom of position of the latter (cf. e.g. true sentence adverbials such as the derivations in -weise: Glücklicherweise, etc., which cannot be used in the pre-front field but anywhere else). What we have called 'dependent clauses' cannot be equated with the 'dependent clauses' of written standard German, since the latter require main clause syntax, while those in the pre-front field by definition do not. What we have called 'conjunctions' in our analysis of spoken German are partly 'subjunctions' in written standard German,

${ }^{15}$ It will be noted that this finding contradicts the stereotype that oral language typically lacks the verbal means to express relations between propositions in a sophisticated way, an assumption that played an important role in Bernstein-type sociolinguistics. 
where they co-occur with the verb-final syntax of German subordinated clauses, etc.

The general reason for which traditional syntax-based categories cannot be taken at face value in an analysis of the pre-front field is that the pre-front field is a more peripheral position in the topology of the German sentence than the front, middle or end field: It has almost no morphosyntactic links with the rest of the sentence (which I will call the 'inner sentence frame' here for convenience). The absence of morphosyntactic links is nicely shown by the difference between the 'hanging topics' discussed in section 2.3., which are part of the pre-front field and have no resumptive pronoun within the inner sentence frame, and 'left dislocations' (prolepses) which do have such a resumptive pronoun.

Loose syntactic attachment makes the pre-front field interactionally attractive: It projects something else to come, but does not oblige the speaker to subscribe to one particular syntactic project at a time where $s /$ he may still be in the phase of planning. At the same time, loose syntactic attachment is also responsible for the high number of grammaticalization processes which converge in this topological position. Some of them will be discussed in this section.

Grammaticalization research is concerned with finding language-specific or universal 'clines'. "The term 'cline' itself has both historical and synchronic implications. Form a historical perspective, a cline is a natural pathway along which forms evolve, a kind of linguistic 'slippery slope' which guides the development of forms. Synchronically a cline can be thought of as a 'continuum': An arrangement of forms along an imaginary line at one end of which is a fuller form of some kind, perhaps 'lexical,', and at the opposite end a compacted and reduced form, perhaps 'grammatical'." (Hopper \& Traugott 1993: 6f) I want to suggest two such clines, chosing predominantly the synchronic perspective.

The first cline is

sequential move > turn-initial move > pre-front field constituent (> constituent in the inner sentence frame)

It is just one instance of the classical cline from interaction (conversation) to syntax (cf. Givón 1979; Hyman 1975; for causal clauses, cf. Couper-Kuhlen, in this volume). A dialogical, sequential structure is condensed and 'compacted' into a grammatical one in which the structure is no longer open to interactional negotiation, but weakly (and later on possibly strongly) adjoined grammatically.

The second cline almost looks like the opposite:

adverbial phrases in the inner sentence frame

subordinating conjunctions $>\quad \begin{aligned} & \text { pre-front field } \\ & \text { constituents }\end{aligned}>\quad \begin{aligned} & \text { discourse } \\ & \text { markers }\end{aligned}$

matrix sentences

In this case, a constituent moves out of the grammatical centre of the sentence into its periphery; at the same time, its semantic meaning is bleached and its scope widened, while it takes on pragmatic meaning as a discourse marker. Processes of 
this type have been described, e.g., by Romaine \& Lange 1991 and Erman \& Kotsinas $1993 .{ }^{16}$ With regard to German, we need to note, however, that discourse markers are not restricted positionally to the beginning or end of a unit (sentence, clause, intonational phrase, turn, etc.). We therefore need to work with a wider, i.e. functional rather than distributional notion of 'discourse markers' than instance Schiffrin (1987) for English.

Evidence for the first cline is perhaps most compelling for vocatives and other pre-front field constituents which may be used as summons in conversation. The most interactional stage of the cline is a sequential structure such as the following:

(16) ("Spatn") (( $\mathrm{A}=$ caller wants to talk to $\mathrm{B}$, but $\mathrm{H}$ answers the phone; both $\mathrm{A}$ and $B$ are called 'Klaus'))

A: $\quad g i b=m=m a l$ hér?

$\mathrm{H}: \quad{ }^{\circ}(\mathrm{j} \text { Awoll })^{\circ}-$ ffff $K$ Klaus!

(1.0)

$\{f f\}$ da Klaus is da;

(1.0)

$\{f f\}$ da Klaus is=am telefon;

(1.0)

$\{f f\}$ wo soi $=i=d a=s$ hí:schdejn;

(0.75)

A: $\quad j^{\prime} a ́ a=j a$

$\{m f\}$ hoid $i$ vabind $=$ di schnäi gäi?

A: give him to me

$\mathrm{H}: \quad$ (sure) - $\{\mathrm{fff}\} \underline{\text { Klaus! }}$

$\{\mathrm{fff}\}$ Klaus is there;

$\{\mathrm{fff}\}$ Klaus is on the phone;

$\{\mathrm{fff}\}$ where should I put it;

A: $\quad$ yeah $=$ yeah

$\{\mathrm{mf}\}$ hold on I put you through o.k.?

If an address term is used as a summons, its position is that of an initiative, first pair part in a sequence; it requires a response by the addressed party. Only after this response (in the telephone data, it likely occurs during the one-second break, not audible for caller A.) can (and indeed, must) the first speaker continue. The interactional function of this sequence is usually to establish a focussed interaction, i.e. to assure mutual availability for interaction.

The same linguistic structures used for summons may also occur in the

${ }^{16}$ Erman \& Kotsinas 1993 suggest the term pragmaticaliztion for the second and third cline. However, there are also important similarities with the first cline. Traugott (MS 1995) mentions decategorialization, phonological reduction, increase in pragmatic function (usually entailing semantic bleaching and sometimes "subjectivization"), polysemy, which justify treating both clines as grammaticalization clines. 
pre-front field (as, for instance, in extract (15) above). In this case, there is no need, and, in most cases, no space for the recipient to respond after the address term. The sequential summons-answer-continuation sequence is condensed into a syntactic pattern of pre-front field + inner sentence frame, and the two components do not constitute conversational moves each any longer. At the same time, the pragmatic interpretation of the address form becomes more indexical. Since co-presence has been established beforehand, the original function of the summons is no longer valid; instead of a relatively uniform meaning, the pre-front vocative can now take on variety of pragmatic meanings, such as to mark topic shifts or to introduce central or critical conversational moves. ${ }^{17}$

Another sequential pattern on the cline towards an asyndetic pre-front field constituent are conditional/temporal clauses (cf. 2.2. above). These clauses, although syntactically marked as dependent, may be used on their own in German (as well as in English), in particular as a polite form of certain face-threatening acts (like in a request such as: Wenn ich Sie bitten dürfte, mir das abzunehmen? 'if I could ask you to carry this for me?'). As such, they obviously require a second pair part, i.e., a response. This interactional use of conditional clauses is still visible in extract (4), where A's intervention is introduced by the sequential "pre(-pre)"18 'if I may come in at this point briefly'; however, we are not on the purely sequential extreme of the cline any longer, for although the 'request' is acknowledged by participant B.'s $\mathrm{hm}$, the requesting party (A.) does not wait for such a response before he pursues his turn. The "pre(-pre)" still is a prefatory activity, of course, but it introduces a turn which is organized as a complex one irrespective of the recipient's response (which is presumably taken for granted). Further down the cline, no legitimate space for intervention or response is available any more; cf. the more grammaticalized uses of conditional or temporal clauses; cf. (5) and (6).

Pre-front field clauses of this type tend to become routinized and idiomatic; their lexicalization is another piece of evidence for an ongoing process of grammaticalization. Sometimes, these idiomatic and lexicalized pre-front field formulae even move down the cline the final step and can be used in the inner sentence frame - in the pre- or post-field - as well (but not, or only parenthetically, in the middle field). An example are metapragmatic formulae such as offen gestanden 'frankly', kurz (gesagt) 'in short'. On this cline, which is very old, conditional phrases have become integrated into the German front field (cf. for details Behaghel 1929).

Grammaticalization on the interaction-to-grammar cline is also involved, when structures typically used in conversation for responsive moves - in particular, for comments and evaluations - are re-categorized as projecting, pre-front field structures. One case are adverbials such as natürlich, sicher, klar another are agreement tokens such as okay, gut. There natural locus of occurrence is that of acknowledgement or agreement moves, adjacent to some other party's activity:

${ }^{17}$ A very similar point can be made for deverbal attention getters such as komm!, schau!, hor!, sag! which are equally bleached semantically but pragmatically enriched when they occur in the pre-front field; for an early analysis along these lines, cf. Wunderlich 1894.

${ }^{18}$ Cf. Schegloff 1980. 


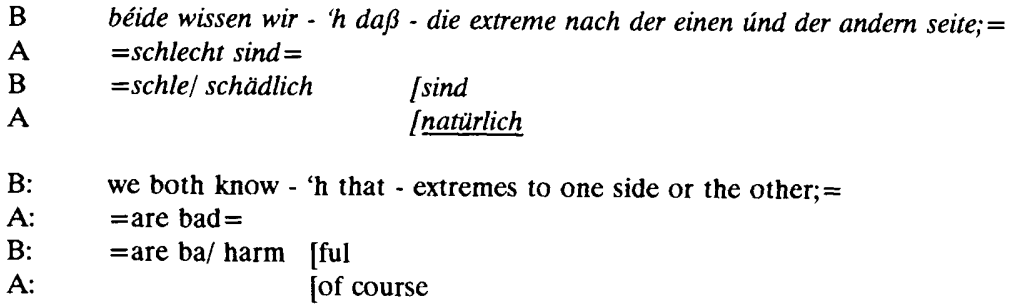

In this case, the sequential and semantic orientation of the adverbial is clearly backwards: Speaker A agrees with speaker B. ${ }^{19}$ Slightly on the cline towards grammaticalization, the same adverbials and agreement tokens may be used as turn-initial components which both respond to the prior other party's contribution and introduce a more complex turn component:

(18) ("Hausrat" Stern [telephone conversation between client and insurance representative])

((client complains about the behaviour of the insurance companies who, in her opinion, take the costumers for a ride; her own contract has been terminated by the company))

$\mathrm{V}: \quad((.)) j e ́ d$.$e versicherungsgesellschaft will gewinne machen,$

$\mathrm{Kd}: \quad$ ham sie ja auch gemacht mit ihren privatversicherungen; nicht - das ging ja alles durch die presse; jetzt haben sie ja getrennte rechnungslegung; weil =se ja jetzt auch ihre ganzen - was weiß ich was die da alles gemacht haben; das haben sie ja alles mit den kleinen kunden - da - reingeholt.

$\mathrm{V}: \quad$ ja natürlich jeder verdient sein géld, aber ich mein =ich kann natürlich verstéhen, das darf man dem versicherer nicht 'übelnehmen, wenn er [...] von der káufmännischen seite sagt jetzt $k$ 'ündige ich den vertrag;

R: every insurance company wants to make profit,

Cl.: this is what they did with these private insurances; didn't they - it was all in the press; now they have separate tendering of account; because they now did their whole - I don't know what they did; they - got it all back from the small - custumer.

R. yes of course, everybody makes his money, but I mean=I can understand of course, you must not blame the insurance company, if it [...] says from the commercial side of the coin now I terminate this contract

Here, natürlich 'of course' is syntactically and pragmatically ambiguous; it both comments on and agrees with Cl.'s prior blame and projects the present speaker's following turn-component, 'everybody makes his own money.

But in a pre-front field usage of natürlich 'of course' as in ex. (2), the sequential environment is different: There is no prior turn by another participant to which the adverbial refers. Instead, the pre-front field adverbial (or agreement token) introduces a syntactic gestalt in the middle of a complex turn, for instance a long argument. Semantically, these pre-front field agreement adverbials and

${ }^{19}$ Note that natürlich 'naturally' has already undergone semantic bleaching in this context. 
tokens often preface a possible counter-argument, which the speaker presumes to be relevant in some kind of imagined dialogue with a partner who is not necessarily identical with the one co-present. This counter-argument, although it has not been made by the other party, at least not explicitly and not in the prior turn, is taken up and 'agreed with' in a yes-but strategy. It is easy to see how this metaphorical extension of the primary interactional usage of agreement adverbials and tokens opens the way to grammaticalization into a connective with quasi-conjunctional function.

It is presumably on this cline that some of the German modal particles came into being - in particular, standard German ja (meaning: 'as we both know'), doch (meaning: 'I assume that you will agree or concur') and Bavarian fei $(<$ fein, lit. 'fine', now roughly meaning: 'contrary to what you may assume'). They are exclusively used in the inner sentence frame today and have therefore reached the most grammatical pole of the cline.

Evidence for the second cline, which turns elements of the inner sentence frame into discourse markers, comes from the development of (sentence) adverbs. Maybe the most spectacular example is the word also, which started out (and may still be used) as a connective adverbial in the inner sentence frame, indicating a consecutive relationship between the clause into which it is incorporated, and the preceding one(s):

(19) ("Legag" [telephone])

R: $\quad$ nuja; - \{più f\}du kommst (kommst) du mal nach Brémen? - so ingendwánn mal nö, [oder so;]

$\mathrm{T}: \quad$ [ne:: jetz] demnächst also: -énde: - öh október=aber wieder nur für ganz kurz

$\mathrm{R}: \quad{ }^{\infty}(\text { só so dann } m)^{\infty}$ lérnst also lieber da: in Kóblenz. -

$\mathrm{T}$ : $\quad$ ja dás sowiesó

R: well then; - are you are you coming to Bremen? - one of these days [or so;

$\mathrm{T}$ : [no:: now very soon you see: - end of - ehm - october = but again just for a very short time only

R: (I see in that case) so you rather study down there in Koblenz. -

$\mathrm{T}$ : oh that is for sure

This semantically rather well delimited use of also 'so' as an adverb which indicates some kind of consequence of what has been previously said (in this case, a conclusion R. draws from T.'s statement that she will not be able to see him in Bremen for quite some time) is quantitatively of minor importance in spoken German, however. Instead, also has assumed a multitude of contextually determined pragmatic meanings, and is predominantly used for for structuring discourse. For these discourse functions, it occurs in fixed and circumscribed sequential and/or syntactic environments. For instance, it is frequently used as a repair marker (as in ex. (20)) or as a pre-closing token (as in ex. (21)):

(20) ("Fernseher" [service team calling at the house of a client whose TV set does not work properly]) 
B: $j a$ ?

T: $\quad$ gschbroche (.) ?na hat sie uns mitgeteilt daß de (.) empf'änger, also férnseh $\{$ acc\}empfänger

B: \# defekt war, lund beim Fachhandwerk isch,

B: $\quad$ [mhm,

T: ((we)) again talked to - your mother I think it was wasn't it?

B: yes?

T: then she informed us that the (.) receiver $\underline{\text { mean }}$ the TV receiver was broken, [and is in the repair shop

B: $\quad[\mathrm{mhm}$,

(21) ("Spatn" [Bavarian dialect])

A: $\quad g l r^{\prime} u ̈ \beta$ schlön;

H: $\quad$ [oké $\quad$ [also pfiadd $=d e ;=$

A: $\quad=g r^{\prime} u ̈ \beta=s c h o ̈ n ; g e \quad[i$ ?

H: $\quad$ [ja mach $=i$; serv/us

A:

loké

$\begin{array}{llll}\text { A: best } \quad \text { [greetin[gs! } & \\ \text { H: } & \text { [fine [0.k. bye then; } & \\ \text { A: } & \text { =best greetings; o. } \quad \text { [k.= } & \\ \text { A: } & & \text { [yes o.k.; che } & \text { [ers } \\ \text { A: } & & & \text { [o.k. }\end{array}$

However, the most frequent usage of also is that of a semantically unspecific opening for a turn or move. In this case, the former adverbial occupies the pre-front field position; cf. (22):

("Mercedes") ((M. wants to buy a new car))

M: ?a:: eh $i$ muß des $=$ no=a bißle (.) beschlafn und no=a=baar gesch ${ }^{\prime} a ̈ f t l e ~ m u ß ~ i$ no mache vorher;

F: $\quad m:$

M: $\quad h i=$ mein wenn $/$ and $/$ de/d/also $=i=h a b$ mich entschlossn - eh:: nicht Porsche des des is $=$ des mach $=i$ auf jedn Fall nicht;

M: well eh I have to sleep (.) over it and do some business I have to do before that;

F: $\quad \mathrm{m}:$

M: ' $\mathrm{h}$ I mean if/ oth/the/ th/ $\underline{\text { see }}=\mathrm{I}=$ made up my mind - eh: not Porsche this this is I won't do that in any case

It is important to note that in this pragmatic usage, also can not be used in the front field; if moved into that position, it would re-assume its original consecutive meaning. Positionally, adverbial usage in the inner sentence frame and pre-front field usage exclude each other. A further, and complete semantic bleaching is involved, if also is used as a mere hesiation marker, comparable to a filled pause. It may then occupy positions in the middle field as well. ${ }^{20}$

20 Also as a hesitation marker is somewhat idiosyncratic, i.e. some speakers use it pervasively, others rarely at all. A story similar to that of also could be told about the (former) modal adverb irgendwie, 'somehow' which has undergone similar semantic bleaching to a discourse 
Another striking example for the second cline are 'matrix sentences' of type 2.5. Starting point of the cline are simple, prosodically integrated 'matrix sentences' in the pre-front field which can still be construed as semantically intact, i.e. as expressing the speaker's believes:

("Allein" Fischer 1991 [radio phone-in])

B: $\quad$ also ich glaúbe hier müssen (sie nen) ersten schritt máchen, u:nd zu einer berátungsstelle gehn, ' $h$ äh eheberatungsstelle oder auch? - zu einer frauenberatungsstelle, \{faster\}das gibt's ja auch, ich glaub frau Bo/ frau Storkebaum weiß da méhr bescheid wie ich \#

B: $\quad$ well I think in this case (you) need to do the first step, and to to an advice centre, 'h ehm marriage advice centre or as well - to a women's advice centre, because this exists too, I think Ms Bo/ Ms Storkebaum knows that better than I do

But particularly the first person forms ich glaube, ich meine undergo considerable phonetic reduction: Radical compression of the pronoun up to pre-palatalization or total loss, and elision of the final schwa is usual: [ ${ }^{j}$ glaËbñ], $\left[{ }^{j}\right.$ maên]. The remaining phonetic substance is used like a modal adverb:

(24) ("Bulimie 9231" [last group therapy session of a series])

TM: $\quad$ warum isch/ heut äger in der gruppe; - warum sind Sie heut (0.5) gran:tig mitenander und.argerlich und (1.0)

$\mathrm{U}: \quad s$ muss doch irgendwas sein

TM: já:. (4.0) ghört des nit áu dezu, (1.5) jetzt, =wahrschéinlich ghörts auch zum ábschied, (8.0) ((clears throat))

A: $\quad$ weniger zum ábschied; = vielleicht zum éndspurt;

(0.5)

$[\ldots]$

A?: $\quad$ so glaub i schón; ja. (4.0)

A: $\quad\{p\}$ glaub bei mír isch des schó so (bissel); (1.0)

TM why is/ there this bad mood in the group today; - why are you today (0.5) ill-tempered with each other and - cross and (1.0)

U: it has got to be something

TM: yes. (2.0) isn't that part of it, (1.5) now=probably it is another part of taking leave, (8.0) ((clears throat))

A: $\quad$ not so much part of leave-taking; = maybe part of the last 100 yards;

$[\ldots]$

A? well I think it is; yeah. (4.0)

A: (I) think for me it is a little bit like that; (1.0)

A final step is reached when glaub '(I) think', mein '(I) mean' etc. are used as discourse particles in other positions of the sentence as well (in particular after the left sentence brace), as it can be observed in ex. (20), line 1. However, in this case we cannot be sure if the marker is a reduced form of ich glaube or of glaub ich. Only the first qualifies as a pre-front field constituent, while the latter might rather

marker and, finally, mere hesitation signal. 
be called a 'post-end field constituent'.

On the second cline, the discourse marker bitte 'please (lit. I beg)' (but not its pragmatic companion danke! 'thanks (lit. 'I thank [you])') is likely to have developed from a matrix sentence (ich bitte [Dich] daß ...'I beg [you])' via the pre-front field position. Just like glaub and mein, it can be used in the pre-front field and also in the middle field, but never in the front field. A number of pre-front field adverbials such as klar 'sure (lit. clear)', möglich 'possible' which share this restriction (but partly cannot stand in any other position of the inner sentence frame either) may be seen as grammaticalized versions of more complex matrix sentences involving the copula sein 'to be' (to be).

\section{Concluding remarks}

In this paper, I have analysed a syntactic position of spoken German which is highly relevant for spoken language but does not accord with the canonical, written sentence. All examples discussed have something in common, which can be stated in syntactic terms, yet in terms of a syntax which is already related to interaction and, in particular, turn-taking. The basic pattern is one that opens up a new syntactic gestalt, i.e., on their own, constituents in this position cannot form a turn-constructional unit. On the other hand, although it is clear that something more is to come, the newly begun gestalt is so underdetermined (open) that no precise predictions can be made about what kind of syntactic structure is going to emerge. I have argued that such an underdetermined syntactic opening can be of interactional advantage if the syntactic structure so begun is also the beginning of a turn-at-talk.

In the second part of this paper, I have given a number of examples which show that the pre-front field is an important grammaticalization position for German. On two 'clines' grammaticalization was observed: One from interactional sequence via turn-initial position to pre-front field syntax (and possible onwards to syntactization into the inner sentence frame); the other, almost inverse, from a structure within the tight syntactic construction of the sentence via the pre-front field to discourse markers.

\section{Appendix}

Transcription conventions

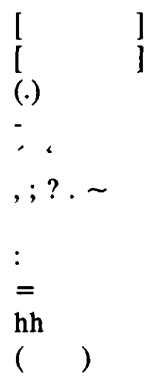

simultaneous talk

micro-pause

pause below $0.5 \mathrm{sec}$

primary/secondary accent of I-phrase

post-nuclear pitch movement (slight rise, slight fall, full rise, full

fall, level)

elongation

latching

in-breath

unintelligible 
$\begin{array}{ll}{[\ldots]} & \begin{array}{l}\text { omission } \\ \text { break-off } \\ \text { diminuendo, crescendo until \# }\end{array}\end{array}$

\section{References}

Allerton, D.J. \& Alan Cruttenden (1974) English sentence adverbials: Their syntax and their intonation in British English. Lingua 34: 1-30.

Auer, Peter (1991) Vom Ende deutscher Sätze. Zeitschrift für Germanistische Linguistik 19.2: 139-157.

Auer, Peter (1992) The neverending sentence: On rightward expansion in spoken syntax. In M. Kontra \& T. Váradi (eds.), Studies in Spoken Language. Budapest: Hungarian Academy of Sciences, pp. 41-60.

Auer, Peter (1996) On the prosody and syntax of turn-continuations. In E. Couper-Kuhlen \& M. Selting (eds.), Prosody in Conversation. Cambridge: Cambridge University Press, pp. 57-100.

Auer, Peter (in press) Formen und Funktionen der Vor-Vorfeldbesetzung im Gesprochenen Deutsch. In P. Schlobinski (ed.,) Syntax des gesprochenen Deutsch. Opladen: Westdeutscher Verlag.

Behaghel, Otto (1929) Der Nachsatz. PBB 53: 401-418.

Bergmann, Jörg (1994) Kleine Lebenszeichen. Über Form, Funktion und Aktualität von Grußbotschaften im Alltag. In W.M. Sprondel (ed.), Die Objektivitat der Ordnungen und ihre kommunikative Konstruktion. Frankfurt, pp. 192-225.

Chafe, Wallace (1985) Linguistic differences produced by differences between speaking and writing. In D.R. Olson et al. (eds.), Literacy, Language, and Learning. Cambridge: Cambridge University Press, pp. 105-123.

Erman, Britt \& Ulla-Britt Kotsinas (1993) Pragmaticalization: The case of ba' and you know. Studier i modern språkvetenskap, New Series Nr. 10, Stockholm: Almqvist \& Wiksell, pp. 76-92.

Givón, Talmy (1979) From discourse to syntax: Grammar as a processing strategy. In Givón (ed.), Discourse and Syntax, New York, pp. 81-111.

Faucher, Eugène (1976) Exceptions à la règle V 2? Cahiers d'Allemand Bd. 11, Paris, pp. 27-47.

Fischer, Rotraut (1991) Disfluenz als Kontextualisierungshinweis in telefonischen Beratungsgesprächen im Rundfunk. Unveröffentl. Magisterarbeit, Universität Konstanz.

Hopper, Paul J. \& Elizabeth C. Traugott (1993) Grammaticalization. Cambridge: Cambridge University Press.

König, Ekkehard \& Johan van der Auwera (1988) Clause integration in German and Dutch conditionals, concessive conditionals, and concessives. In J. Haiman \& S. Thompson (eds.), Clause Combining in Grammar and Discourse. Amsterdam/Philadelphia: Benjamins Publishing Company, pp. 101-133.

Matthiessen, Christian \& Sandra Thompson (1988) The structure of discourse and 'subordination'. In J. Haiman \& S. Thompson (eds.), Clause Combining in Grammar and Discourse. Amsterdam/Philadelphia: Benjamins Publishing Company, pp. 275-329. 


\section{2}

Quirk, Randolf \& Sidney Greenbaum (1973) A University Grammar of English. London \& New York: Longman.

Romaine, Suzanne \& D. Lange (1981) The use of like as a marker of reported speech and thought: A case of grammaticalization in progress, American Speech 66/3: 227-279.

Schegloff, Emanuel (1980) Preliminaries to preliminaries: Can I ask you a question?. Soc. Inqu.: 104-154.

Schegloff, Emanuel (1996) Turn-organization: One intersection of grammar and interaction. In E. Ochs, E.A. Schegloff \& S. Thompson (eds.), Interaction and Grammar. Cambridge: Cambridge University Press.

Schiffrin, Deborah (1987) Discourse Markers. Cambridge: Cambridge University Press.

Schröder, Peter (1984) Wortstellung in der deutschen Standardsprache. Mannheim 1984.

Selting, Margret (1993) Voranstellungen vor den Satz. Zeitschrift für Germanistische Linguistik 21: 291-319.

Sweetser, Eve (1990) From Etymology to Pragmatics. Cambridge: Cambridge University Press.

Thim-Mabrey, Christiane (1988) Satzadverbialia und andere Ausdrücke im Vor-Vorfeld. Deutsche Sprache 16: 52-67.

Traugott, Elizabeth C., MS (1995) The role of the development of discourse markers in a theory of grammaticalization.

van de Velde, Marc (1978) Zur mehrfachen Vorfeldbesetzung im Deutschen. In M.E. Conte et al. (eds.), Wortstellung und Bedeutung. Akten des 12. Linguistischen Kolloquiums, Paris 1977. Tübingen: Niemeyer, pp. 131-144.

Wunderlich, Hermann (1894) Unsere Umgangsprache in der Eigenart ihrer Satzfügungen. Weimar and Berlin. 